SOUTHERN BRAZILIAN JOURNAL OF CHEMISTRY

SOUTH. BRAZ. J. CHEM., Vol. 12, No. 12, 2004

\title{
CATARINA, SOUTH AMERICA`S FIRST HURRICANE. A SIGNAL OF GLOBAL CLIMATIC CHANGES
}

\author{
Lavinel G. Ionescu ${ }^{* a, b}$ and B. K. Sumner ${ }^{c}$ \\ ${ }^{\text {a }}$ Scienco Consulting Services \\ Viamão, Rio Grande do Sul, BRASIL \\ barmisegetusa Research Group \\ Santa Fe, New Mexico, USA \\ ${ }^{\text {c}}$ Rocket City Consultants \\ Alamogordo, New Mexico, USA
}

\begin{abstract}
On March 27, 2004 a strong storm (tropical cyclone) hit the coast of Southern Brazil and caused death and widespread devastation in part of the States of Santa Catarina and Rio Grande do Sul. In spite of what some Brazilian meteorologists initially had to say, Catarina was South America's first hurricane. Many Brazilian meteorologists, for various reasons, did not want to recognize that it was a real hurricane and classified the phenomenon as an extratropical cyclone, a polar low or even a hybrid occurrence. Catarina initiated about $1000 \mathrm{~km}$ off the Brazilian Coast (Santa Catarina) around March 20, 2004 as an extratropical cyclone (EC), underwent tropical transition (TT) and subsequently became a cathegory I hurricane. It was really South America's first hurricane and it may be a possible indication of global climate changes.
\end{abstract}

\section{RESUMO}

Em 27 de Março de 2004 uma grande tempestade (ciclone extratropical) atingiu o Sul do Brasil, incluindo parte dos Estados de Santa Catarina e Rio Grande do Sul. A maioria dos meteorologistas brasileiros, por várias razões, não quis reconhecer que de fato se tratava de um verdadeiro furacão e classificou o acontecimento como um ciclone extratropical (CE), um fenômeno híbrido ou algo similar. Catarina começou á cerca de $1000 \mathrm{~km}$ da costa do Brasil (Santa Catarina) em torno de 20 de Março de 2004 como um ciclone extratropical (CE), foi sujeito á um transição tropical (TT) e subsequentemente se transformou num furracão de categoria I. Foi verdadeiramente o primeiro furacão observado na América do Sul e pode ser uma possível indicação de mudança climática global. 
A hurricane is an intense storm of tropical origin with wind speeds exceeding 120 $\mathrm{km} / \mathrm{hr}$ (64 knots or $74 \mathrm{mi} / \mathrm{hr}$ ) which forms over warm waters of the Northern Atlantic and Eastern North Pacific Oceans. The word hurricane comes from the Mayan storm god, Hunraken. In general, a hurricane is a large rotating storm where the winds move around a relatively calm center called the eye. In the Western Pacific the hurricanes are called typhoons, in the Philippines baguios and cyclones in India and Australia.

Hurricanes arise from tropical cyclones that spiral off the west coast of Africa and Central America, usually in the later summer and early fall. They lash the Caribbean, the Atlantic Coast States of the U.S. and at times they also hit Mexico from the Pacific. Typhoons arise from tropical cyclones, reach the coast along the Northwest Pacific Ocean and usually hit Japan, Korea and the Philippines. Cyclones (that are really typhoons or hurricanes) also hit at times India, Australia, Tahiti, Fiji and Samoa. Arctic cyclones (winter storms) that pack hurricane force winds are formed at times in the North Atlantic and may batter the British Isles. Figure 1 illustrates the regions where hurricanes usually form and the pathways they usually take. ${ }^{1-3}$

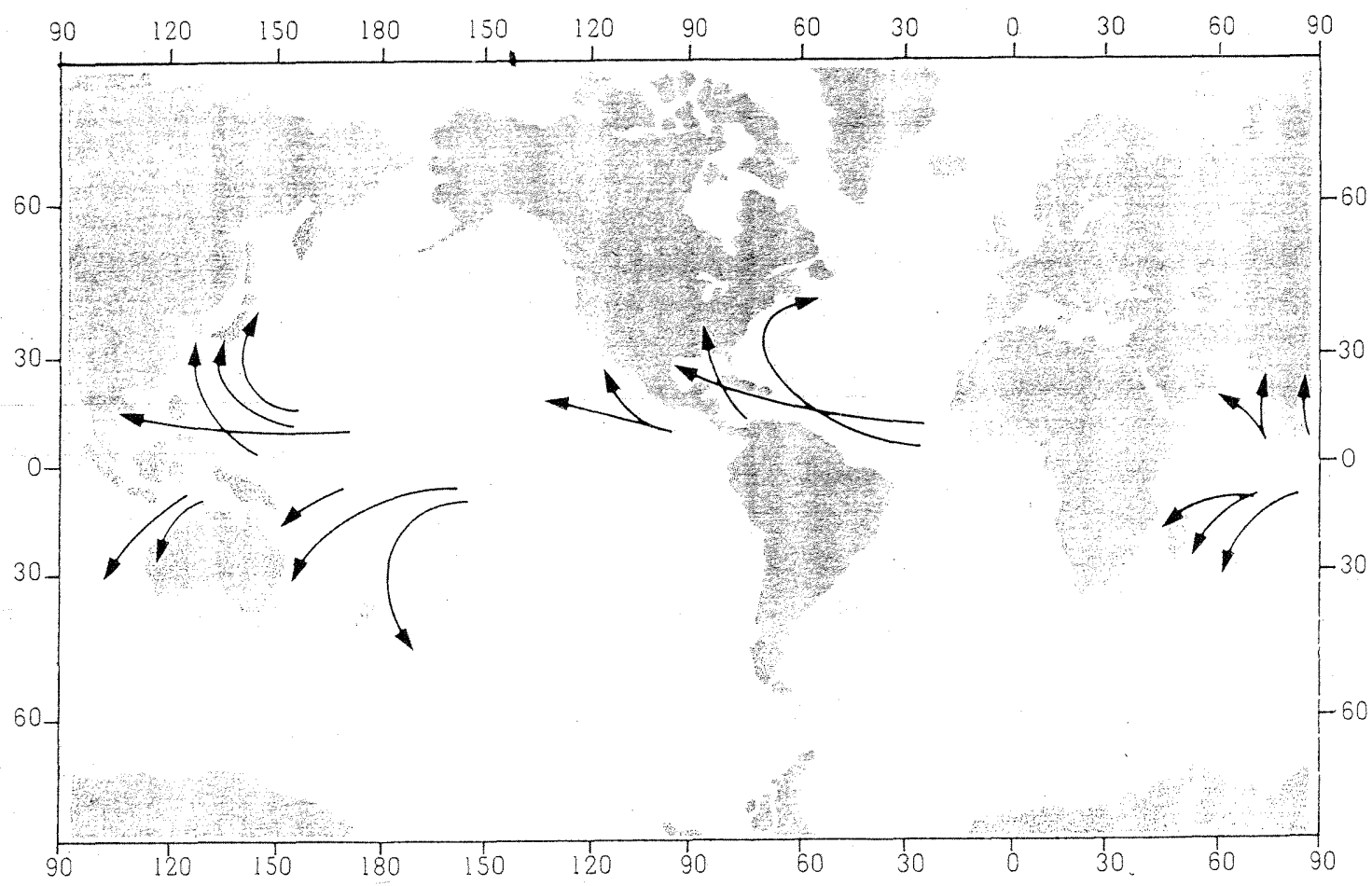

Figure 1. Regions of the Earth where hurricanes usually form and the pathways they commonly take.

Strangely, South America is generally believed to be protected from hurricanes. They do not form off the west coast because the water of the Pacific is too cold and strong winds over the South Atlantic shear off the tops of developing cyclones before they reach peak power. ${ }^{4-11}$ 
Hurricane form over tropical waters where the winds are light and the surface water temperature is warm over a vast area. Sea surface temperature is usually above $26.5^{\circ} \mathrm{C}$ and at a depth of $50 \mathrm{~m}$. This type of conditions prevail over the tropical North Atlantic and North Pacific Oceans during the summer and early fall. Normally, the hurricane season lasts from June to November.

In order for a mass of unorganized thunderstorms to develop into a hurricane, the surface winds must converge. In the Northern Hemisphere, converging air spins counterclockwise, while in the Southern Hemisphere the spinning is clockwise. This type of rotation does not develop on the equator where the Coriolis force is zero. A distance of about $10^{\circ}$ latitude from the equator is necessary for a Coriolis Effect strong enough to prevent filling of the central low pressure (center of the hurricane).

Hurricanes form in subtropical regions, usually between $10^{\circ}$ and $20^{\circ}$ latitude.

Convergence may occur along a front that has moved from middle latitude into the tropics. Developing thunderstorms and converging surface winds may form, particularly when the front is accompanied by a cold upper level trough. Surface winds converge along the intertropical convergence zone (ITCZ). Sometimes, when the ICTZ is displaced away from the equator, a wave in the ITCZ forms into an area of low pressure, convection becomes organized and the system grows into a hurricane. ${ }^{1-3}$

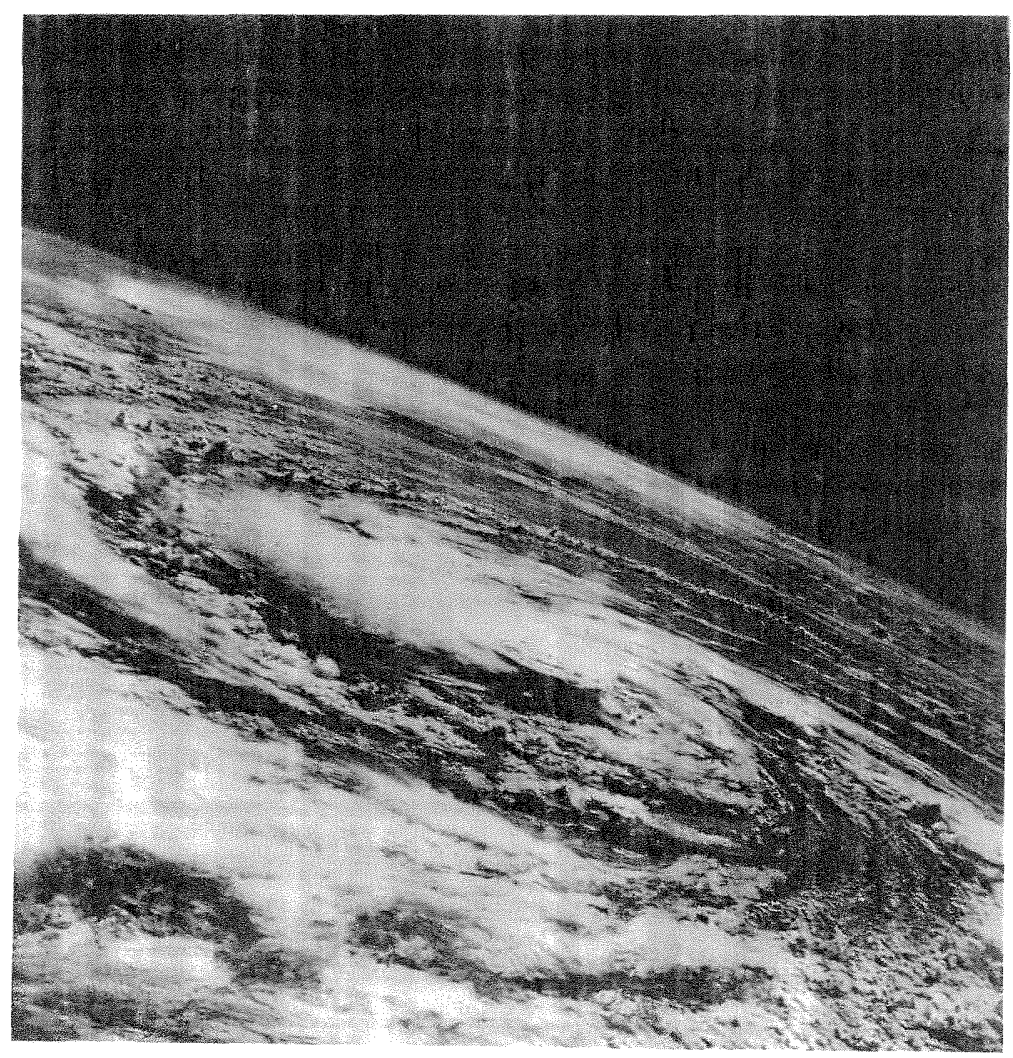

Figure 2.Photograph from the Apollo 7 spacecraft of hurricane Gladys about $150 \mathrm{~km}$ southwest of Tampa, Florida (Courtesy of NASA -National Aeronautics and Space Administration and Sarmisegetusa Research Group-SRG, Santa, New Mexico, USA) 
Figure 2 shows Hurricane Gladys, a typical hurricane. The picture was taken from the Apollo 7 Spacecraft when the storm was off the coast of Florida. A typical hurricane has a diameter of approximately $500 \mathrm{~km}$. The area in the center is called the eye and its diameter usually varies from 20 to $50 \mathrm{~km}$. Within the eye, the winds are light and clouds are usually broken. The surface air pressure is very low, usually about $950 \mathrm{mb}$. The dark blotches in the eye correspond to regions where the sky is clear. The clouds align themselves in bands (rain bands) that spiral in towards the storm center where they wrap themselves around the eye. The surface winds increase in speed as they blow counterclockwise (Northern Hemisphere) and inward toward the center. Around the eye is the eye wall, a ring composed of intense thunderstorms that whirl around the storm center and may extend upward to about $15 \mathrm{~km}$ above the sea level. The strongest winds and the heaviest precipitation are normally found within the eye wall. At times the winds may surpass 120 knots.

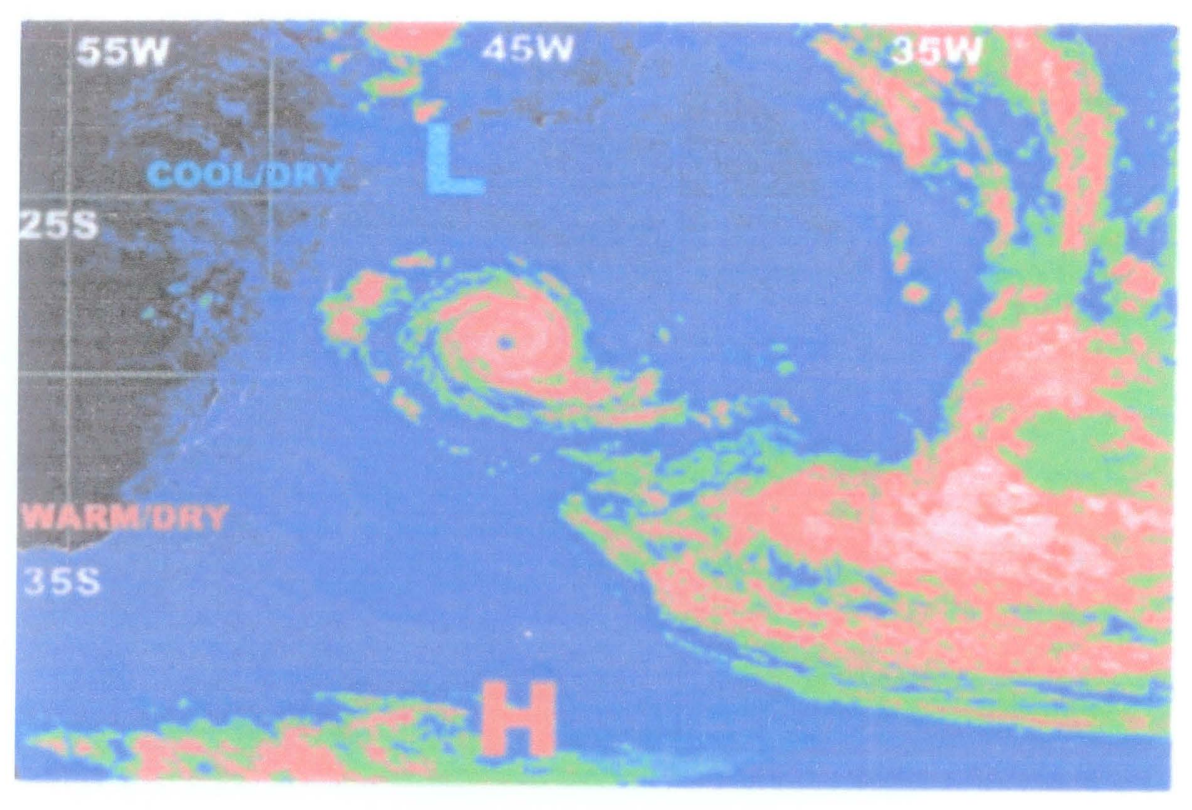

Figure 3. Enhanced image of Catarina obtained from the GOES-12 infrared channel. (Courtesy of NASA and Sarmisegetusa Research Group, Santa Fe, New Mexico, USA)

Figure 3 is an enhanced image from the GOES -12 meteorological satellite infrared channel obtained on March 26, 2004 showing Catarina approaching the Brazilian Coast. The position of the upper level ridge and trough is indicated by letters $\mathrm{H}$ and $\mathrm{L}$, respectively. Regions of warm/dry and cool/dry surface air over the continent are also shown.

Figure 4 is a three-dimensional image of Catarina on May 272004 obtained from the National Aeronautics and Space Administration -NASA. The hurricane had a diameter of about $400 \mathrm{~km}$ and the eye had a diameter between 25 and $40 \mathrm{~km}$. The estimated minimal central pressure inside the eye was estimated about $974 \mathrm{hPa}$ or mb. 


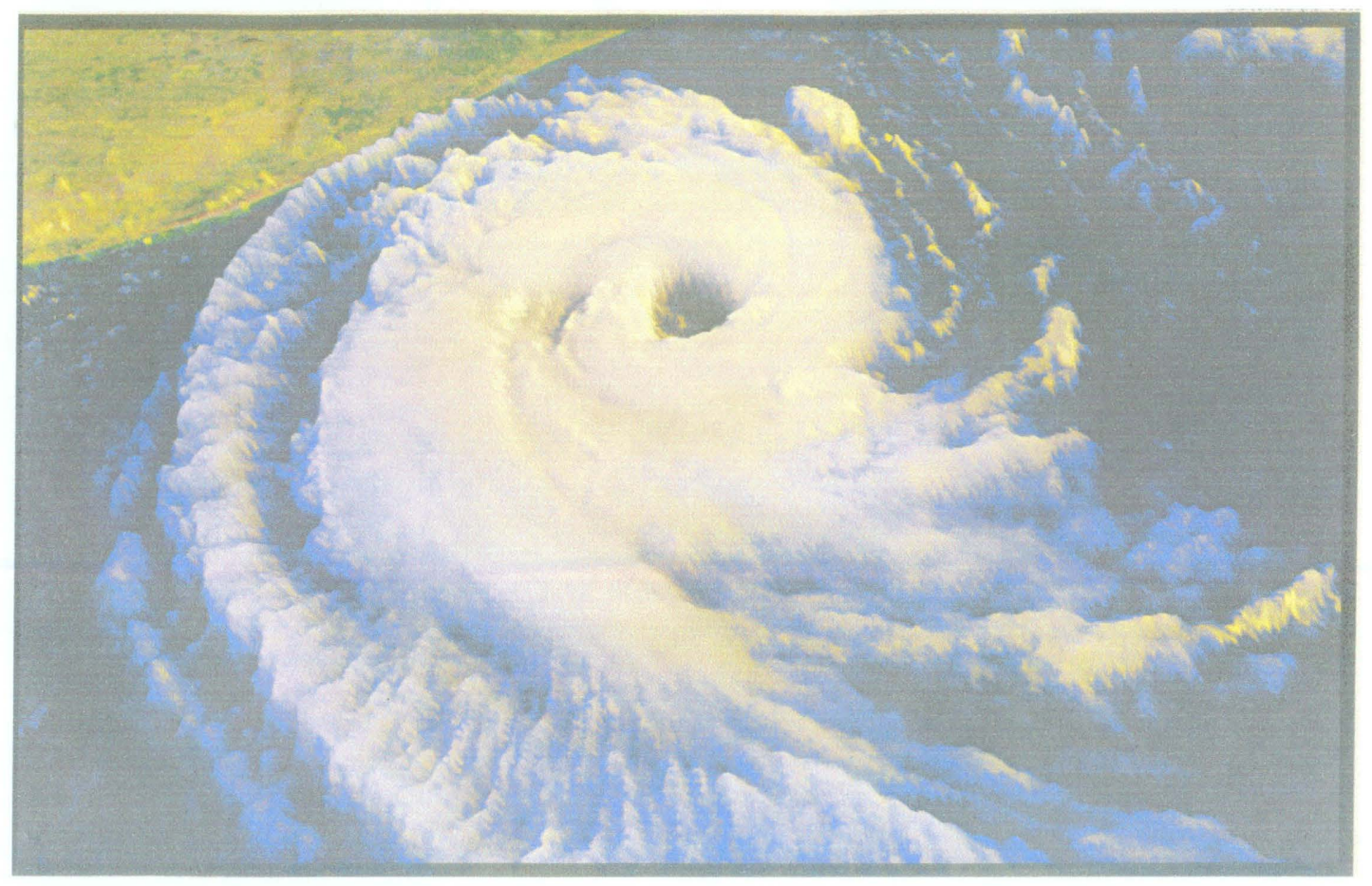

Figure 4. Three-dimensional image of Catarina on March 27, 2004 obtained from NASA (Courtesy NASA and Sarmisegetusa Research Group, Santa Fe, New Mexico, USA).

The surface winds had hurricane force and ranged between 120 and $150 \mathrm{~km} / \mathrm{hr}$. According to the criteria described above, Catarina was classified as a type I hurricane on the Saffir-Simpson scale. During its trajectory, Catarina covered a route of more than $3000 \mathrm{~km}^{4-12}$

According to available meteorological data, Catarina began as an extratropical cyclone (EC) in a frontal system around March 20, 2004 about 1000km off the coast of the Brazilian State of Santa Catarina. Two days later it underwent tropical transition (TT) under continuous low vertical wind shear over average water temperatures. Subsequently, Catarina reached cathegory I hurricane strength under an unusual combination of low wind shear and strong mid to high latitude blocking.

Meteorologists like Jack Bevan of the National Hurricane Center of the United States in Miami, Florida, observed the hurricane three days before it hit the Brazilianm Coast and monitored its course and development. Brazilian authorities were informed unofficially about the unusual phenomenon.

On the other hand, Marcelo Seluchi, Director of CPTEC (Centro de Previsão do Tempo e Estudos Climáticos) of the Instituto Nacional de Pesquisas Espaciais-INPE in São José dos Campos, SP, and other Brazilian meteorologists insisted initially that Catarina was an extratropical cyclone (EC), that its center was colder than its rims and that the winds were spinning in the same direction at the surface and higher levels. ${ }^{5}$ 
Catarina is the first South Atlantic hurricane that has been documented to the present date. There are two other cases of weak tropical cyclones (TC) below hurricane strength that may have happened during the era of satellite monitoring.

Large scale phenomena and anomalies at mid to high latitudes may be related to the mechanism that led to the formation of this hurricane. ${ }^{6-11}$ Catarina may be a signal of global climatic change.

\section{REFERENCES}

1. C. Donald Ahrens, "Meteorology Today - An Introduction to Weather, Climate and Environment", $3{ }^{\text {rd }}$ edition, West Publishing Company, San Francisco, California, USA, 1988.

2. R. A. Anthes, "Tropical Cyclones: Their Evolution, Structure and Effects", Meteorol. Monogr., Vol.19, American Meteorological Society, Boston, Mass., USA, 1982.

3. M. J. Coghlan, A Comparative Climatology of Action in the Two Hemispheres, Austral. Meteorol. Mag.,31, 3-13 (1983).

4.A. B. Pezza and T. Ambrizzi, Variability of Southern Hemisphere Cyclone and Anticyclone Behavior. Further Analysis, J. Clim., 18, 1075-1083 (2003).

5. P.L. Silva Diaz, M.A.F. Silva Diaz, M. Seluchi and F.A. Diniz, O ciclone Catarina: Análise preliminar da estrutura, dinâmica e previsibilidade, Paper presented at the XIII Brazilian Meteorological Society Conference, Fortaleza, Ceará, Brazil, August 29 - September 3, 2004.

6. I.Simmonds and K. Keay, Variability of Southern Hemisphere Extratropical Cyclone Behavior. J. Clim., 13, 550-561 (2000).

7. K. A. Emanuel, The dependence of Hurricanes on Climate, Nature, 326, 483485 (1987).

8. S.B. Goldenberg, J.L. Shapiro and W. M. Gray, J. Clim., 9, 1169 (1996).

9. S. B. Goldenberg, C.W. Landsea, A.M. Mestas-Nuñez and W. M. Gray, The Recent Increase in Atlantic Hurricane Activity: Causes and Implications, Science, 293, 474-479 (2001).

10. M. A. Gan, "Ciclogêneses e ciclones sobre a América do Sul", Tese de Doutorado, Instituto Nacional de Pesquisas Espaciais - INPE, São José dos Campos, SP, Brazil,1992. 
11. P. Satyamarty, C.C. Fereira and M.A. Gan, Cyclonic Vortices over South América, Tellus, 42A,194-201 (1990).

12. G. R. Cunha, J.L.F. Pires and A. Pasinato, "Uma discussão sobre o conceito de hazards e o caso do furacão/ciclone Catarina, EMBRAPA Trigo, Passo Fundo, RS, Brasil, Documentos Online, Dezembro 2004,

http://www.cnpt.embrapa.br/biblio/dop-do36htm

ACKNOWLEDGEMENT. We gratefully acknowledge the help and support of NASA -

National Aeronautics and Space Administration and SRG-Sarmisegetusa Research Group, Santa Fe, New Mexico, USA, 